\section{Lipoproteins Containing Apoprotein B Are a Major Regulator of Neutrophil Responses to Monosodium Urate Crystals}

\author{
Robert Terkeltaub, Linda K. Curtiss, Andrea J. Tenner, \\ and Mark H. Ginsberg \\ Department of Immunology and Division of Rheumatology, \\ Scripps Clinic and Research Foundation, La Jolla, \\ California 92037
}

Lipoprotein-depleted plasma reconstituted with very low, intermediate, and low density lipoproteins (LDL) inhibited crystal-induced CL. High density lipoprotein reconstitution was without effect. Immunodepletion from plasma of all apo B lipoproteins by agarose-bound apo B-specific antibody also removed all inhibitory activity for urate-induced CL. Thus, apo B lipoproteins were shown to be the inhibitory species in plasma. Binding of apo B lipoproteins to urate crystals and inhibition of CL was also seen in the absence of other plasma proteins. In addition, the binding of whole lipoprotein particles to the crystals was verified by detection of crystal-associated cholesterol in addition to the apoprotein.

The effects of LDL on urate crystal-induced CL were stimulus specific. Coincubation of urate crystals and neutrophils in the presence of $10 \mu \mathrm{g} / \mathrm{ml} \mathrm{LDL}$ resulted in $83 \%$ inhibition. In contrast, $\mathrm{CL}$ responses to a chemotactic hexapeptide, opsonized zymosan, and Staphylococcus aureus were not inhibited by LDL.

The effects of depletion of apo B lipoproteins on plasma suppression of urate crystal-induced $C L$ appeared to be unique. Plasmas or sera depleted of other urate crystal-binding proteins including fibrinogen, fibronectin, $\mathrm{Clq}$, and IgG retained virtually all their CL inhibitory activity. Lipoproteins containing apo $\mathrm{B}$ are thus a major regulator of neutrophil responses to urate crystals. These lipoproteins are present in variable concentration in synovial fluid and may exert an important influence on the course of gout.

\section{Introduction}

Monosodium urate crystals appear to trigger attacks of gout (1); yet there is striking variability in the inflammatory response to intra-articular crystals (2-5). The ability of urate crystals to induce inflammation is critically dependent upon neutrophils (6). In response to urate crystals, these cells generate superoxide 
$(7,8)$, a chemotactic factor $(9,10)$, and leukotrienes $(11)$, and release lysosomal enzymes by lytic and nonlytic $(12,13)$ mechanisms. A number of biologically significant proteins bind to urate crystals (14-17) and may influence crystal-induced neutrophil responses $(7,18)$. This suggests that variation in the protein coat of these crystals may be one factor in the variable in vivo inflammatory response in gout.

Since most synovial fluid proteins are present in plasma (19), and plasma and serum have a more constant composition than gouty synovial fluid $(19,20)$, investigators have focused on serum and plasma effects on neutrophil-crystal interaction. Serum profoundly inhibits urate crystal-induced neutrophil lysis (18) and a serum coat has been shown by Abramson et al. (7) to reduce urate crystal-induced superoxide generation. In neither study were the inhibitory factor(s) identified. We have recently established detailed biochemical maps of the protein coat of plasma-exposed urate crystals by O'Farrell two-dimensional gel electrophoresis (17) and observed several hitherto unidentified polypeptides, which were increased on the crystal surface relative to plasma. In the present study, we have identified a number of these polypeptides as derived from lipoproteins. We have also found that lipoproteins containing apoprotein B (apo B) ${ }^{1}$ account for virtually all of the inhibitory activity of plasma on urate crystal-induced neutrophil chemiluminescence and a major portion of the plasma inhibitory activity in urate-induced neutrophil superoxide generation and cytolysis.

\section{Methods}

Crystals and crystal-protein binding studies. Urate crystals were prepared under sterile pyrogen-free conditions by a previously described modification (21) of the method of McCarty and Faires (22) and by the method of Denko and Whitehouse (23) and resuspended to $25 \mathrm{mg} / \mathrm{ml}$ in urate-saturated phosphate-buffered saline (PBS) $(10 \mathrm{mM}$ Na phosphate

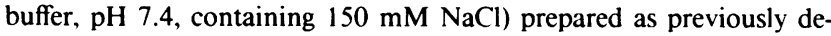
scribed (24). Crystals were utilized in unheated form, were negatively birefringent, and ranged predominantly from $15-45 \mu \mathrm{m}$ in length. Using polarized light microscopy, it was verified that the smaller crystals in these preparations could be phagocytosed by neutrophils. To coat crystals with plasma proteins, equal volumes of crystals and plasma were coincubated at $37^{\circ} \mathrm{C}$ for $30 \mathrm{~min}$ in a total volume of $0.6 \mathrm{ml}$, unless otherwise indicated. Unbound plasma proteins were removed by washing the crystals through $0.8 \mathrm{ml}$ of a $20 \%$ sucrose cushion followed by a wash in $\mathrm{ml}$ urate-saturated PBS. These conditions gave reproducible crystalprotein binding patterns on O'Farrell gels as previously described (17)

Other reagents. Opsonized zymosan was prepared by incubation of zymosan (Sigma Chemical Corp.. St. Louis, MO) with normal human serum at $37^{\circ} \mathrm{C}$ for $15 \mathrm{~min}$ with agitation followed by repeated washing in PBS and storage at $-70^{\circ} \mathrm{C}$. A 200 -fold excess of opsonized zymosan particles to polymorphonuclear leukocytes (PMN) was used in the chemiluminescence (CL) assay (25). Staphylococcus aureus ATCC 25923

1. Abbreviations used in this paper: apo, apolipoprotein: apo A-I, apo B, and apo E, apolipoproteins A-I, B, and E: CL, chemiluminescence; LDH, lactic dehydrogenase: LPDP, lipoprotein-depleted plasma; PAGE. polyacrylamide gel electrophoresis: pI, isolectric point. was a generous gift from Dr. R. Proctor (University of Wisconsin, Madison, WI) and was grown, washed, and lyophilized as described (26). The chemotactic hexapeptide FNLPNTL ( $N$-formyl-N-leu-leu-phe- $N$ leu-tyr-lys) was the generous gift of Dr. L. Sklar, Scripps Clinic and Research Foundation. All other chemicals were reagent grade.

Lipoprotein depletion, isolation and iodination. Lipoprotein-depleted plasma (LPDP) was prepared by ultracentrifugation (27). Plasma containing $20 \mathrm{mM}$ EDTA was adjusted to a density of $1.25 \mathrm{~g} / \mathrm{cm}^{3}$ with solid $\mathrm{KBr}$ and centrifuged at $45,000 \mathrm{rpm}$ for $20 \mathrm{~h}$ at $4^{\circ} \mathrm{C}$ in a fixedangle 50Ti rotor (Beckman Instruments Inc., Spinco Div., Palo Alto, CA). The lipoprotein-containing supernatant was removed and the infranatant taken as LPDP. Reconstituted LPDP was obtained by mixing the supernatant and infranatant. Both LPDP and reconstituted LPDP were dialyzed against 1 liter of $10 \mathrm{mM}$ PBS, pH 7.4, which was changed twice, for a total of $18 \mathrm{~h}$, and their protein concentrations measured and equalized by addition of buffer. Lipoprotein depletion was verified by $>95 \%$ reduction of cholesterol content of LPDP vs. reconstituted LPDP. Lipoproteins were isolated by sequential ultracentrifugation of pooled plasma from normal fasting subjects using solid $\mathrm{KBr}$ for density adjustment as previously described (27). The lipoprotein fractions included very low density lipoprotein (VLDL), $d<1.006 \mathrm{~g} / \mathrm{cm}^{3}$; intermediate density lipoprotein (IDL), $d=1.006-1.019 \mathrm{~g} / \mathrm{cm}^{3}$; low density lipoprotein (LDL), $d=1.019-1.063 \mathrm{~g} / \mathrm{cm}^{3}$; and high density lipoprotein (HDL), $d=1.063-1.25 \mathrm{~g} / \mathrm{cm}^{3}$. The fractions were dialyzed against 0.15 $\mathrm{M} \mathrm{NaCl}$ containing $0.3 \mathrm{mM}$ EDTA and $0.0005 \%$ alphatocopherol, filter sterilized, and stored sterile for a maximum of $7 \mathrm{~d}$. All lipoprotein concentrations are expressed on the basis of protein as measured by a modification of the Lowry assay using a bovine serum albumin (BSA) standard (28). The lipoproteins used displayed a consistent apoprotein composition as judged by sodium dodecyl sulfate-polyacrylamide gel electrophoresis (SDS-PAGE) (27). When labeled lipoproteins were employed, $100 \mu \mathrm{g}$ of VLDL, IDL, LDL, and HDL were labeled enzymatically with $1 \mathrm{mCi}$ of ${ }^{125} \mathrm{I}$ (Amersham Corp., Arlington Heights, IL) using immobilized lactoperoxidase and glucose oxidase (Enzymobeads, Bio-Rad Laboratories, Richmond. CA). They were dialyzed, characterized, and stored aseptically in the presence of $10 \%$ BSA as previously described (29).

Immunodepletion of apo-B lipoproteins. Plasma was depleted of apo B-containing lipoproteins (VLDL. IDL, and LDL) by immunoadsorption with a mouse anti-human apo B monoclonal antibody. V82A6 (27). The monoclonal antibody was immunopurified from ascites fluid as described (29), coupled to CNBr-activated Sepharose 4B (Pharmacia Fine (hemical. Piscataway, NJ), and equilibrated in PBS containing 10 $\mathrm{mM}$ EDTA, $10 \mathrm{U} / \mathrm{ml}$ trasylol, and $5 \mathrm{mM}$ benzamidine. $1 \mathrm{ml}$ of plasma was chromatographed on $15 \mathrm{ml}$ of gel containing $26.3 \mathrm{mg}$ of coupled antibody and the nonretained plasma fraction collected. Apo B removal from the plasma was monitored immunochemically by using a solidphase radioimmunoassay as described (27). The antibody-adsorbed plasma fraction contained $<50 \mathrm{ng}$ apo $\mathrm{B} / \mathrm{mg}$ of plasma protein.

Tw'o-dimensional gel electrophoresis. Urate crystal-bound protein was eluted by boiling for $5 \mathrm{~min}$ in $10 \%$ glycerol, $5 \%$ Nonidet- $40,1.5 \%$ SDS, and $2 \% \beta$-mercaptoethanol, and the protein concentration of the eluates was determined by the Lowry assay using a BSA standard. Samples of purified lipoproteins delipidated by boiling in the same SDS-containing buffer described above, and crystal eluates containing $75 \mu \mathrm{g}$ of protein were analyzed by isoelectric focusing followed by SDS-PAGE in an 8$20 \%$ exponential gradient slab gel in the second dimension as described previously (17). Protein was detected by the silver-staining protocol of Morrissey (30), and isoelectric points and molecular weights estimated as described previously (17) 
Western blot analysis. For Western blot analysis, the slab gels were washed and electrophoretically transferred to nitrocellulose $(0.45 \mu \mathrm{m}$, No. HAWP 304 FO, Millipore Corp., Bedford, MA) as previously detailed (27). The nitrocellulose transfers of O'Farrell gels were soaked overnight in PBS containing 3\% BSA, 3\% normal goat serum, and $0.01 \%$ azide (blocking buffer) to saturate remaining active binding sites, and then incubated with first antibody (hybridoma culture supernatants or ascites fluids) for $18 \mathrm{~h}$ at $4^{\circ} \mathrm{C}$. Sources of apoprotein-specific antibody were: anti-apoprotein A-I (apo A-I) hybridoma AV63C2 (27); anti-apo B hybridomas V82A6 and V82B1 (27); monospecific rabbit polyclonal antiLDL serum (29), and anti-apoprotein E (apo E), hybridoma Emab3 (31). The nitrocellulose membranes were washed five times with blocking buffer containing 0.5\% TWEEN-20 (Sigma Chemical Co.). Mouse antibody was detected on O'Farrell gel blots by addition of ${ }^{125}$ I-goat antimouse $\mathrm{Ig}(0.5 \mu \mathrm{Ci} / \mathrm{ml})$ for $4 \mathrm{~h}$ at $4^{\circ} \mathrm{C}$ followed by washing and detection of ${ }^{125} \mathrm{I}$ by autoradiography as previously described (27). Mouse and rabbit antibodies on blots of single dimensional gels were detected by goat anti-mouse or anti-rabbit IgG conjugated to horseradish peroxidase (Bio-Rad Laboratories) (32).

$P M N$ luminol-dependent $C L$. PMNs were isolated from human blood by the method of Boyum (33) utilizing ficoll-hypaque density gradients and dextran sedimentation with modifications as previously described (34). These preparations contained $>95 \%$ neutrophils. PMN CL assays were performed by using previously described modifications (35) of the method of Wilson et al. (36) and monitored in a Beckman LS-8000 liquid scintillation counter (Beckman Instruments Inc., Fullerton, CA) operated in the single photon counting mode. The assay conditions were $2.5 \times 10^{5}$ cells per assay in a final volume of $0.5 \mathrm{ml}$ Hanks' balanced salt solution (HBSS) containing $0.02 \mathrm{M}$ Hepes, $0.25 \%$ (wt/vol) BSA, and $2 \mu \mathrm{M}$ luminol (Aldrich Chemical Co., Milwaukee, WI). CL was monitored at $22^{\circ} \mathrm{C}$ at intervals of $0.25 \mathrm{~min}$ for $60 \mathrm{~min}$. $\mathrm{CL}$ values are expressed as counts per minute per $2.5 \times 10^{5}$ cells after correction for background $\mathrm{CL}$ obtained in the absence of stimulation. In selected experiments, results were expressed as the maximum $C L$ response to urate crystals. In each instance, this maximum response was observed within 30 min of PMN exposure to the crystals.

Assay of superoxide $O_{\dot{2}}^{\bar{z}}$ generation. To measure $\mathrm{O}_{\overline{2}}^{\overline{2}}$ generation, 2 $\mathrm{mg} / \mathrm{ml}$ urate crystals were added to PMNs at $5 \times 10^{6} \mathrm{ml}$ in $1 \mathrm{ml} \mathrm{HBSS}$ $0.02 \mathrm{M}$ Hepes- $0.25 \% \mathrm{BSA}$ in the presence of $50 \mu \mathrm{M}$ ferricytochrome $C$ (Horse Heart, Sigma Chemical Co.). Experiments were performed in 5 $\mathrm{ml}$ polypropylene tubes at $37^{\circ} \mathrm{C}$ with constant agitation and the reactions were terminated by centrifugation at $500 \mathrm{~g}$ for $10 \mathrm{~min}$ at $4^{\circ} \mathrm{C}$. Cell-free supernatants were decanted and superoxide dismutase-sensitive reduction of cytochrome $C$ was assayed at $551 \mathrm{~nm}$ in a Gilford 240 spectrophotometer (Gilford Instrument Laboratories, Inc., Oberlin, OH) (37). Superoxide dismutase $(10 \mu \mathrm{g} / \mathrm{ml})$ was added to control samples containing crystals. Control samples containing buffer in place of crystals were also included.

PMN cytolysis ( $L D H$ release) assay. Isolated PMNs in HBSS- 0.02 $M$ Hepes- $0.25 \%$ BSA $\left(6 \times 10^{6}\right.$ cells $\left./ \mathrm{ml}\right)$ and urate crystals $(2.5 \mathrm{mg} / \mathrm{ml})$ in a total volume of $0.5 \mathrm{ml}$ were incubated in $5 \mathrm{ml}$ polypropylene tubes at $37^{\circ} \mathrm{C}$ for $1 \mathrm{~h}$ with continuous shaking. Incubations were terminated by addition of $2 \mathrm{ml}$ of iced HBSS and centrifugation at $300 \mathrm{~g}$ for 10 min at $4^{\circ} \mathrm{C}$. Supernatants were decanted for LDH assay. Certain tubes were terminated at time zero as zero time blanks. Cell suspensions lysed by addition of Triton X-100 in HBSS (final concentration, $0.1 \% \mathrm{vol} /$ vol) and sonication were used to determine total enzyme activity. LDH was assayed by oxidation of NADH as previously described (18). Results were expressed as percentage of total enzyme activity by the formula (Enzyme release - zero time blanks/total enzyme) $\times 100$.
Other plasma and protein preparations. Plasma from an asymptomatic patient with acquired agammaglobulinemia was the generous gift of Dr. John Curd, Scripps Clinic and Research Foundation. The IgG concentration of this plasma was $<38 \mu \mathrm{g} / \mathrm{ml}$ by the Mancini method (38). IgM and IgA were undetectable. An aliquot of this plasma was reconstituted with addition of $15 \mathrm{mg} / \mathrm{ml} \mathrm{IgG} \mathrm{(human} \mathrm{Cohn} \mathrm{fraction} \mathrm{II,}$ Calbiochem-Behring Corp., San Diego, CA), which was deaggregated by centrifugation at $28 \mathrm{psi} \times 30 \mathrm{~min}$ in a Beckman airfuge (39). The chloramine $T$ method was used to label IgG (40).

Fibronectin-depleted plasma and fibronectin were prepared and analyzed by gelatin-Sepharose chromatography and radioimmunoassay, respectively (41). Sham fibronectin-depleted plasma was prepared by chromatography on underivatized Sepharose.

Clq-depleted serum was prepared by Biorex 70 chromatography, analyzed, and reconstituted with $\mathrm{Clq}$ as previously described (42).

Determination of crystal-associated cholesterol. To ascertain if native LDL was bound to washed urate crystals, we incubated $12.5 \mathrm{mg} / \mathrm{ml}$ urate crystals in PBS buffer containing $0.8 \mathrm{mg} / \mathrm{ml}$ LDL (final concentration). Crystals were washed as described above and material was eluted from a $5 \mathrm{mg}$ crystal pellet by incubation with $0.45 \mathrm{ml}$ of $1 \mathrm{M} \mathrm{NaCl}$ (14) for $30 \mathrm{~min}$. Urate crystals were removed by sedimentation and total cholesterol was measured in the eluate using the enzymatic spectrofluorometric assay of Heider and Boyett (43) and of Gamble et al. (44). Samples were read in a Perkin-Elmer 650-10S fluorescence spectrophotometer (excitation, $325 \mathrm{~nm}$; emission, $415 \mathrm{~nm}$ ) (Perkin-Elmer Corp., Norwalk, CT).

Statistical methods. Results were analyzed statistically using the Student's $t$ test (two-tailed).

\section{Results}

Identification of apolipoproteins bound to urate crystals. We have previously noted several unidentified polypeptides selectively bound to plasma-exposed urate crystals (17). To determine if any of these polypeptides were apolipoproteins, we compared the urate bound polypeptides of plasma and LPDP by twodimensional O'Farrell gel electrophoresis $(17,45)$. Three apolipoproteins (apo A-I, apo B, and apo E) were identified among the eluted polypeptides which were consistently absent or reduced when LPDP rather than undepleted plasma was used to coat the urate crystals (Fig. 1, arrows numbered 1-4). The apolipoproteins showed similar mobilities to polypeptides of isolated lipoproteins on O'Farrell gels. In addition, when isolated ${ }^{125} \mathrm{I}$ lipoproteins were added to plasma before coating the urate crystals, the ${ }^{125}$ I coelectrophoresed with these crystal-bound polypeptides (not shown). Details of lipoprotein class origin and apparent $M_{\mathrm{r}}$ and isoelectric point (pI) for the identified apolipoproteins (apo A-I, apo B, and apo E) appear in Table I. Details of immunochemical identification were as follows. A polypeptide (Fig. 1, arrow number 3) with apparent $M_{\mathrm{r}}=36,000, \mathrm{pI}=4.5-$ 4.8, which was present in isolated VLDL and IDL (gels not shown), contained an epitope reactive with an apo E-specific monoclonal antibody (Fig. 2) and was thus apo E. Similarly, a polypeptide (Fig. 1, arrow number 4) with apparent $M_{\mathrm{r}}=26,000$, $\mathrm{pI}=4.6-4.8$ was identified as apo A-I because it was present in isolated HDL (gels not shown) and possessed an epitope reactive with an apo A-I-specific monoclonal antibody (Fig. 2). 


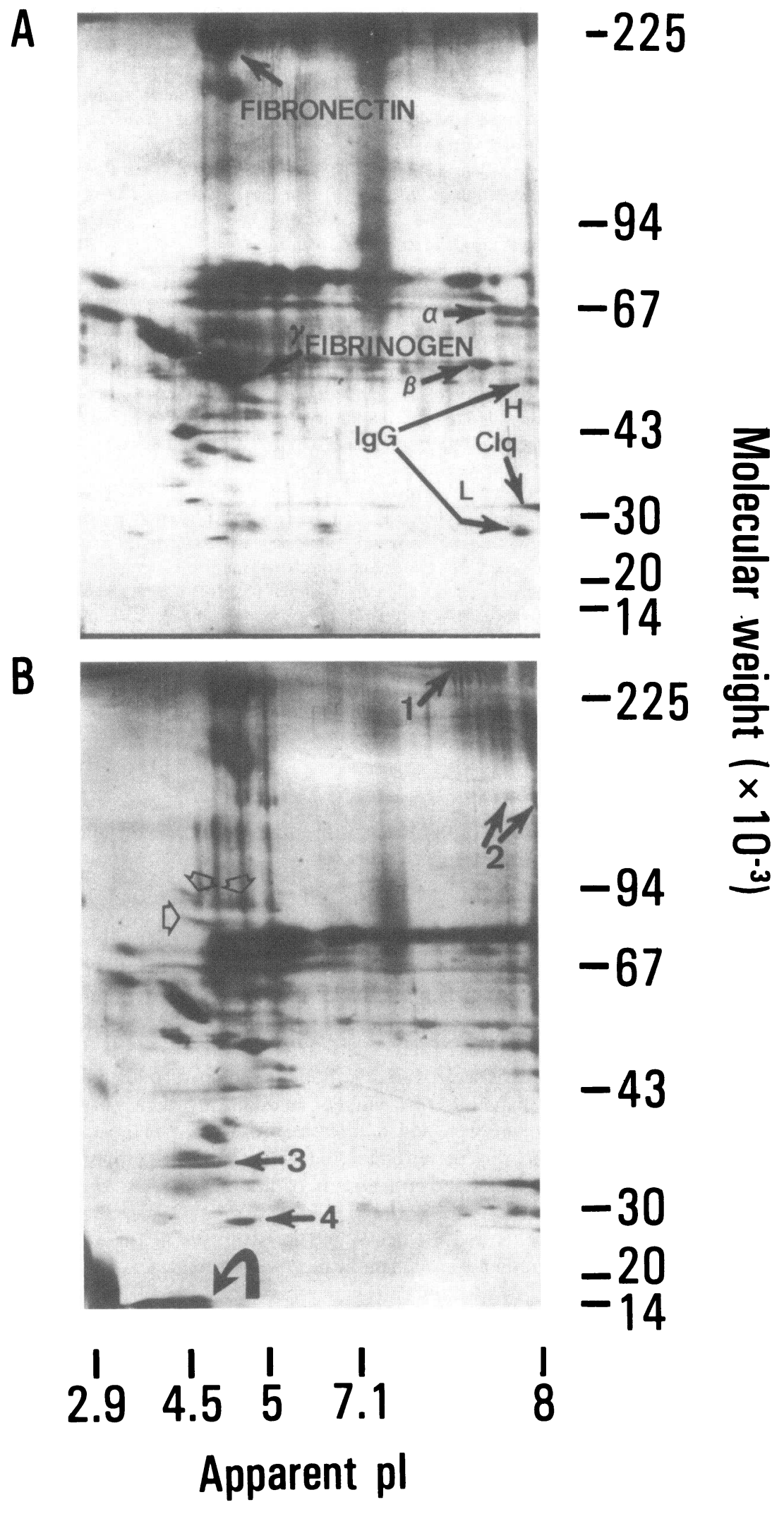

Figure 1. Identification of urate crystal-bound apolipoproteins by two-dimensional O'Farrell gel electrophoresis. After incubation of urate crystals with LPDP (gel A), or reconstituted LPDP (gel B), proteins eluted from the washed urate pellet were run in an isoelectric focusing gel under reducing conditions in the first dimension (right to left) and in an 8-20\% exponential gradient SDS-PAGE slab gel in the second dimension (top to bottom). This figure shows the silver-staining patterns of a $75-\mu \mathrm{g}$ protein load. Arrows on gel A indicate certain polypeptides represented in abundance on both gels (fibronectin, fibrinogen $\alpha, \beta$, and $\gamma$ chains, IgG heavy (H) and light (L) chains, and Clq). Arrows 1-4 on gel B indicate urate-bound apolipoproteins diminished by plasma lipoprotein depletion (gel A) and identified immunochemically (Table I, Figs. 2 and 3). Open-headed arrows indicate urate-bound polypeptides which comigrated with LDL-derived material but were not identified by Western blot analysis. The curved arrow indicates a group of polypeptides which comigrated with protein from VLDL, IDL, and HDL. 
Table I. Immunochemically Identified Urate Crystal-bound Apolipoproteins on O'Farrell Gels*

\begin{tabular}{|c|c|c|c|c|c|}
\hline $\begin{array}{l}\text { Arrow } \\
\text { on } \\
\text { Fig. } 1\end{array}$ & $\begin{array}{l}\text { Apparent } \\
M_{\mathrm{r}}\left(10^{3}\right)\end{array}$ & $\begin{array}{l}\text { Apparent } \\
\text { pl }\end{array}$ & $\begin{array}{l}\text { Diminished } \\
\text { by } \\
\text { lipoprotein } \\
\text { depletion }\end{array}$ & $\begin{array}{l}\text { Coelectrophoresis } \\
\text { with } \\
\text { apoproteins } \\
\text { from: }\end{array}$ & $\begin{array}{l}\text { Identification } \\
\text { by } \\
\text { Western } \\
\text { Blot }\end{array}$ \\
\hline 1 & $>250$ & $7.2-8$ & + & $\begin{array}{l}\text { VLDL, IDL, } \\
\text { LDL }\end{array}$ & apo B \\
\hline 2 & 148 & $7.2-8$ & + & LDL & apo B \\
\hline 3 & 36 & $4.5-4.8$ & + & VLDL, IDL & apo $\mathrm{E}$ \\
\hline 4 & 26 & $4.6-4.8$ & + & HDL & apo A-I \\
\hline
\end{tabular}

* Gels shown in Fig. 1.

Urate crystal-bound apo B was identified as follows. Polypeptide number 2 (Fig. 1, apparent $M_{\mathrm{r}}=148,000$, pI 7.2-8.0) was present in isolated LDL and was bound by an apo B-specific monoclonal antibody (Fig. 2). In addition, its migration was similar to that described by Kane et al. (46) for the apo B-26 species of LDL and it was thus identified as apo B. Polypeptide number 1 (Fig. 1, apparent $M_{\mathrm{r}}>250,000$, pI $=7.2-8.0$ ) was a major crystal-bound species and was observed in gels of isolated VLDL, IDL, and LDL. Its low mobility in SDS gels suggested that it represented apo B-100 (46). However, this polypeptide was only poorly transferred electrophoretically from O'Farrell gels to nitrocellulose paper, and under these conditions, was not detected by overlay with monoclonal anti-apo B antibody. In another approach, isolated LDL and proteins eluted from urate crystals exposed to plasma were applied to $3.3-6 \%$ exponential gradient SDS-PAGE gels without prior isoelectric focusing. The gels were electrophoretically transferred to nitrocellulose, as described above, followed by overlay with two different murine monoclonal antibodies and a rabbit polyclonal antiserum specific for human LDL (Fig. 3). Antibody binding was then detected with horseradish peroxidase-conjugated specific IgG. Polypeptides with an apparent $M_{\mathrm{r}}$ of 500,000 and 142,000 , respectively, were identified immunochemically as apo $B$ by all three antibodies in urate crystal eluates (Fig. 3; lanes $1 a, 2 a, 3 a$ ). The 500,000 polypeptide was identified also in native LDL (Fig. 3; lanes $1 b, 2 b, 3 b$ ) and presumably represents apo B-100 (46). Another urate-bound apo B polypeptide with apparent $M_{\mathrm{r}}=300,000$ was identified by murine monoclonal antibody V82B1 (lane $2 a$ ) and seen as a closely spaced doublet with rabbit polyclonal anti-apo B serum (lane $1 a$ ). Inspection of the polypeptides eluted from urate crystals (Figs. $1 A, B$ ) also revealed that a number of polypeptides, which comigrated with minor species in isolated LDL and possessed apparent $M_{\mathrm{r}}$ from 90,000 to 94,000 , were present only in reconstituted LPDP (Fig. $1 B$, open-headed arrows). These peptides probably represented apo $B$ fragments $(47,48)$. In addition, a group of low molecular weight anionic polypeptides (Fig. $1 B$, curved arrow), which comigrated with protein in VLDL, IDL, and HDL, was eluted from plasma-exposed urate crystals. These polypeptides were

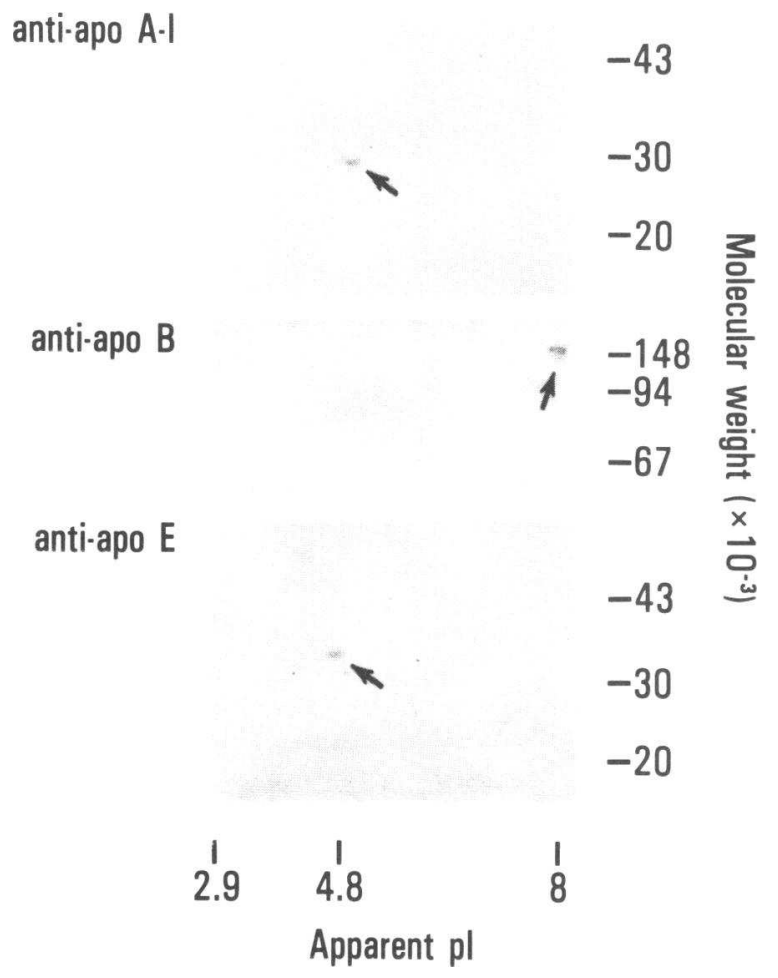

Figure 2. Immunochemical identification of urate crystal-associated apolipoproteins by Western blot. 2-D gels containing $200 \mu \mathrm{g}$ of urate crystal-associated plasma proteins were electrophoretically transferred to nitrocellulose membranes and incubated with murine anti-apo A-I, anti-apo B (V82A6), and anti-apo E monoclonal antibodies. Antibody binding was detected by a second incubation with ${ }^{125}$ I-labeled anti-mouse Ig followed by autoradiography. The figure shows sections of autoradiographs from three different transfers with arrows pointing to the identified apolipoproteins.

presumed to represent urate-bound apoprotein A-II or one of the apoprotein $C$ subclasses (60), but further identification was not attempted.

Effect of lipoprotein depletion of plasma on the neutrophilurate crystal interaction. To investigate the effects of crystalbound lipoproteins on urate crystal-induced neutrophil stimulation, we utilized luminol-dependent CL. CL reflects changes in neutrophil oxidative metabolism (49) and offers the advantages of sensitivity, ease of quantitation, and kinetic measurements on a single sample. Urate crystals induced dose-dependent $\mathrm{CL}$ at crystal concentrations from 0.1 to $10 \mathrm{mg} / \mathrm{ml}$ (data not shown); a dose of $2 \mathrm{mg} / \mathrm{ml}$ urate crystals, which produced a slightly submaximal response, was chosen for CL experiments.

As previously described for urate crystal-induced neutrophil cytolysis (18) and superoxide generation (7), we found that plasma and serum precoating of the crystals suppressed (>50\%) the $\mathrm{CL}$ response relative to that obtained with uncoated crystals (Fig. $4 A$ ). In contrast, precoating of urate crystals with LPDP led to a $\mathrm{CL}$ response quantitatively similar to the response to 


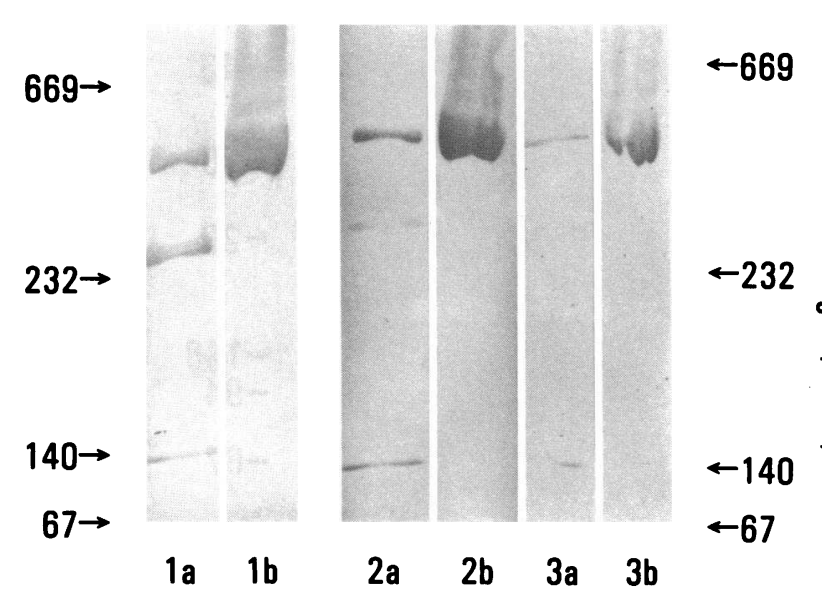

Figure 3. Further identification of urate crystal-bound apo B by Western blot analysis. Single-dimensional 3.3-6\% exponential gradient SDS-PAGE slab gels were run under reducing conditions, and then, electrophoretically transferred to nitrocellulose membranes and incubated with anti-apo B antibodies as indicated below. Antibody binding was detected by a second incubation with anti-mouse (or anti-rabbit) IgG conjugated to horseradish peroxidase. The figure is a composite of nitrocellulose transfers from gels containing isolated LDL and plasma proteins eluted from urate crystals. Lanes $1 b, 2 b$, and $3 b$ contained $35 \mu \mathrm{g}$ isolated LDL; lanes $1 a, 2 a$, and $3 a$ eluate from $5 \mathrm{mg}$ plasma-exposed urate crystals; lanes $1 a$ and $b$ were overlaid with monospecific rabbit polyclonal anti-LDL serum and were from a separate gel; lanes $2 a$ and $b$ were overlaid with murine antiapo B monoclonal antibody V82B1; and lanes $3 a$ and $b$ were overlaid with murine anti-apo B monoclonal antibody V82A6.

uncoated crystals (Fig. $4 \mathrm{~B}$ ), despite the fact that numerous plasma proteins were bound to the crystals (Fig. $1 \mathrm{~A}$ ). Reconstitution of LPDP with the $d<1.25 \mathrm{~g} / \mathrm{cm}^{3}$ fraction of plasma reconstituted the plasma inhibition of CL (Fig. 4). When plasmas were coincubated with cells and crystals, inhibition of CL, which was reversible by lipoprotein depletion, also was observed (data not shown).

To determine if lipoprotein-associated inhibition of urate crystal-induced CL correlated with inhibition of other cellular responses, we assayed superoxide generation and cytolysis. Precoating urate crystals with plasma (reconstituted LPDP) inhibited crystal-induced superoxide generation as expected (Table II, $50 \%$ inhibition), and this inhibition was significantly reduced by lipoprotein depletion (18\% inhibition). Neutrophil lysis was assessed by urate crystal-induced lactic dehydrogenase (LDH) loss (Table III). Lipoprotein depletion from plasma resulted in marked reduction of the suppressive effect of plasma (reconstituted LPDP) on cytolysis.

Identification of apo B-containing lipoproteins as the major inhibitory species. To determine which lipoproteins participated in plasma inhibition of urate crystal-induced neutrophil simulation, we reconstituted LPDP with physiologic concentrations
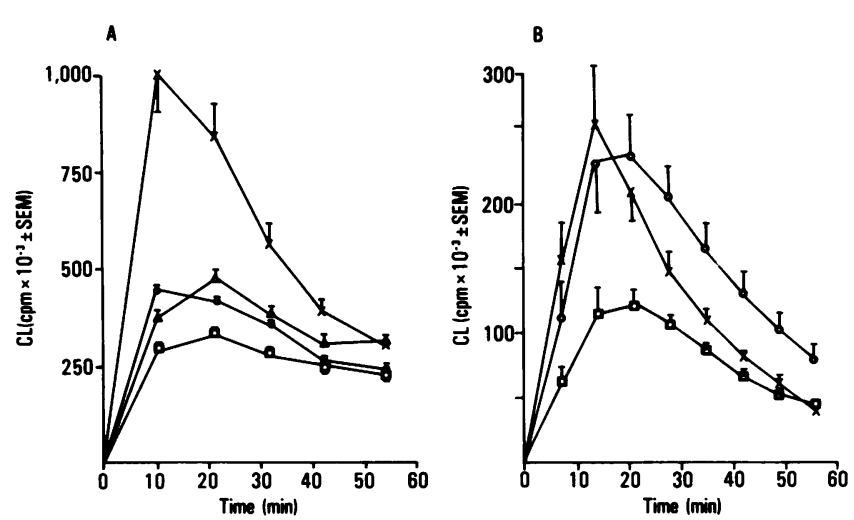

Figure 4. Effect of preincubation of urate crystals with plasma and serum on the crystal-induced $C L$ response. $(A)$ Unmodified serum and plasma. $2.5 \times 10^{5} \mathrm{PMNs}$ were incubated in HBSS buffer containing $0.02 \mathrm{M}$ Hepes, $0.25 \% \mathrm{BSA}$, and $2 \mu \mathrm{M}$ luminol at $22^{\circ} \mathrm{C}$, and background CL was determined in a Beckman LS-8000 Scintillation counter (Beckman Instruments, Inc., Fullerton, CA) in the out of coincidence mode. At zero time, additions were made in triplicate of 1 $\mathrm{mg}(2 \mathrm{mg} / \mathrm{ml})$ urate crystals which had been coated with buffer $(-\times-), 5$ mM EDTA plasma (- - - ), $0.38 \% \mathrm{Na}$ citrate plasma $(-\Delta-)$, and serum $(-\square-)$ from the same donor. CL was monitored for $60 \mathrm{~min}$ at $22^{\circ} \mathrm{C}$. CL values are expressed here and throughout the paper as counts per minute corrected for background observed in the absence of stimuli. All CL experiments were performed two or more times and representative experiments are shown. $(B)$ Effect of lipoprotein depletion of plasma on inhibition of urate crystalinduced PMN CL. LPDP and reconstituted LPDP were adjusted to equal protein concentrations. Urate crystals at $25 \mathrm{mg} / \mathrm{ml}(0.3 \mathrm{ml})$ were incubated with $0.6 \mathrm{ml}$ of these plasmas or buffer and washed. Crystals coated with buffer $(-\times-)$, LPDP $(-0-)$, and reconstituted LPDP (- -$)$ were added to PMNs and CL was assayed as described.

of isolated VLDL, IDL, LDL, and HDL (50), and used these plasmas to coat urate crystals. The washed crystals were then assayed for their ability to induce $C L$ relative to uncoated crystals. As shown in Table IV $A$, LDL reconstitution had the largest inhibitory effect (78\% inhibition of peak crystal-induced $\mathrm{CL}$ ), VLDL and IDL were active (52\% and $46 \%$ inhibition, respectively), and HDL was inactive. This suggested that the apo Bcontaining lipoproteins (VLDL, IDL, and LDL) were the active species. To confirm this, plasma was depleted of apo B-bearing lipoproteins by immunoaffinity chromatography (see Methods). Apo B was undetectable in the antibody adsorbed plasma $(<50$ $\mathrm{ng} / \mathrm{mg}$ plasma protein). Apo-B depletion completely abrogated the CL inhibitory effect of plasma (Table IV $B$ ), and this demonstrated that apo B-containing lipoproteins are a major inhibitor of urate crystal-induced CL.

Binding of individual lipoproteins to urate crystals and their effect on CL. To determine if the binding of plasma lipoproteins to urate crystals and the effects of bound lipoproteins on PMN stimulation were direct or dependent on the presence of other 
Table II. Effect of Bound Lipoproteins on Urate Crystal-induced Superoxide $\left(O_{\bar{z}}\right)$ Generation

\begin{tabular}{lll}
\hline & $\begin{array}{l}\text { Cytochrome } C \text { reduction } \\
(\text { nmol/10 cells/30 min } \pm \text { SEM) }\end{array}$ & $\begin{array}{l}\text { Inhibition of } \\
\text { crystal-induced } \mathrm{O}_{\tilde{z}} \\
\text { generation }\end{array}$ \\
\hline Stimulus & & $\%$ \\
$\begin{array}{l}\text { No addition (control) } \\
\text { Uncoated urate crystals }\end{array}$ & $0.63 \pm 0.03$ & - \\
$\begin{array}{l}\text { Urate crystals coated } \\
\text { with LPDP }\end{array}$ & $2.24 \pm 0.15$ & - \\
$\begin{array}{l}\text { Urate crystals coated } \\
\text { with reconstituted } \\
\text { LPDP }\end{array}$ & $1.63 \pm 0.15^{*}$ & 18 \\
\hline
\end{tabular}

PMNs $\left(5 \times 10^{6} / \mathrm{ml}\right)$ in $1 \mathrm{ml}$ HBSS- $0.02 \mathrm{M}$ Hepes- $0.25 \%$ BSA were simulated by the addition of $2 \mathrm{mg} / \mathrm{ml}$ uncoated or plasma-coated urate crystals for $30 \mathrm{~min}$ at $37^{\circ} \mathrm{C}$ in the presence of $50 \mu \mathrm{M}$ ferricytochrome $C$. Cell-free supernatants of the reaction mixtures were assayed spectrophotometrically for superoxide dismutase-sensitive reduction of cytochrome $C$. These are pooled results from two experiments, each performed in triplicate.

$* P<0.01$ vs. urate crystals coated with LPDP.

bound plasma proteins, we utilized plasma-free systems. We first assessed the binding of isolated, radioiodinated VLDL, IDL, LDL, and HDL to urate crystals (Fig. $5 A$ ). Periphysiologic lipoprotein concentrations were used to reproduce plasma conditions as in the previous experiments. Lipoprotein binding to urate crystals was detected with each of the radioiodinated classes. At physiologic concentrations, the largest quantity of bound lipoprotein was obtained with LDL. The effects of bound purified lipoproteins on urate crystal-induced $\mathrm{CL}$ were simultaneously

Table III. Effect of Lipoprotein Depletion on Plasma Inhibition of Urate Crystal-induced PMN Cytolysis

\begin{tabular}{lll}
\hline $\begin{array}{l}\text { Stimulus: urate crystals } \\
\text { coated with: }\end{array}$ & LDH release & $\begin{array}{l}\text { Inhibition relative } \\
\text { to uncoated crystals }\end{array}$ \\
\hline & $\begin{array}{l}\text { \% of } \\
\text { total } \pm \text { SEM }\end{array}$ & $\%$ \\
& $77.2 \pm 0.7$ & - \\
PBS (uncoated crystals) & $64.3 \pm 3.7$ & 17 \\
LPDP & $29.9 \pm 1.5^{*}$ & 62 \\
Reconstituted LPDP & &
\end{tabular}

Urate crystals $(2.5 \mathrm{mg} / \mathrm{ml})$ precoated with LPDP or reconstituted LPDP were incubated in quadruplicate with $6 \times 10^{6}$ PMNs in a total volume of $0.5 \mathrm{ml} \mathrm{HBSS}-\mathrm{Hepes}-\mathrm{BSA}$ at $37^{\circ} \mathrm{C}$ for $60 \mathrm{~min}$. Percent total LDH released per cell suspension was measured. Results are from an experiment representative of five separate experiments.

$* P<0.001$ vs. LPDP coated crystals.
Table IV. Effect of Reconstitution of LPDP with Isolated Lipoproteins $(A)$ and Effect of Removal of Apo B-containing Lipoproteins $(B)$ on the Plasma Inhibition of Urate Crystal-induced $C L$

\begin{tabular}{llc}
\hline $\begin{array}{l}\text { Stimulus: urate crystals } \\
\text { coated with: }\end{array}$ & $\begin{array}{l}\text { Maximum CL } \\
\text { (cpm } \pm \text { SEM) }\end{array}$ & $\begin{array}{l}\text { Inhibition } \\
\text { of CL (\%) }\end{array}$ \\
\hline & & $\%$ \\
A. Buffer (control) & $254,040 \pm 56,585$ & - \\
LPDP & $248,958 \pm 30,032$ & 2 \\
LPDP + VLDL & $122,220 \pm 11,162$ & 52 \\
LPDP + IDL & $136,223 \pm 2,635$ & 46 \\
LPDP + LDL & $56,098 \pm 3,819$ & 78 \\
LPDP + HDL & $264,267 \pm 26,246$ & 0 \\
B. Buffer (Control) & $523,702 \pm 31,883$ & - \\
Apo B-depleted plasma & $510,309 \pm 102,669$ & 3 \\
Plasma & $275,838 \pm 22,144$ & 47 \\
\hline
\end{tabular}

(A.) Lipoproteins were added to LPDP to restore physiologic concentrations (VLDL, $0.12 \mathrm{mg} / \mathrm{ml}$; IDL, $0.1 \mathrm{mg} / \mathrm{ml}$; LDL, $0.9 \mathrm{mg} / \mathrm{ml}$; $\mathrm{HDL}, 1.5 \mathrm{mg} / \mathrm{ml}$ ) and the plasmas were incubated with urate crystals. Precoated washed crystals $(2 \mathrm{mg} / \mathrm{ml})$ were added in triplicate to PMNs for assay of $C L$ as previously described. Maximum CL refers to the highest $\mathrm{CL}$ observed within $\mathbf{3 0}$ min of the addition of the crystal stimuli. (B.) In a separate experiment, plasma was depleted of apo $B$ by immunoaffinity chromatography employing a murine monoclonal anti-apo B antibody (V82A6). Apo B-depleted plasma and starting plasma $(0.8 \mathrm{ml})$ diluted to identical protein concentrations were incubated with $0.2 \mathrm{ml}$ of a $25 \mathrm{mg} / \mathrm{ml}$ urate crystal suspension. Washed precoated crystals $(2 \mathrm{mg} / \mathrm{ml})$ were subsequently added to PMNs in quadruplicate and CL was monitored.

measured (Fig. 5 B). VLDL, IDL, and LDL were inhibitory, and LDL had the greatest quantitative effect at physiologic input concentrations. In contrast, crystal-bound HDL did not inhibit urate crystal-induced $\mathrm{CL}$ at the concentrations tested.

To demonstrate association of intact LDL particles with urate crystals, the washed urate crystal pellet was assayed for total cholesterol after incubation of $12.5 \mathrm{mg} / \mathrm{ml}$ crystals with a periphysiologic concentration of LDL $(0.8 \mathrm{mg} / \mathrm{ml})$. Urate crystalbound cholesterol $(5.3 \mu \mathrm{g} / \mathrm{mg}$ urate crystal) was detected and confirmed the binding of native LDL.

Stimulus specificity of lipoprotein inhibition of $C L$. To determine if the inhibitory effect of apo B-containing lipoproteins on CL was stimulus-specific, we added LDL, without washing, to urate crystals, and to two other solid-phase stimuli ( $S$. aureus and opsonized zymosan) and one fluid-phase stimulus (chemotactic hexapeptide $N$-formyl- $N$-leu-leu-phe- $N$-leu-tyr-lys). 10 $\mu \mathrm{g} / \mathrm{ml}$ LDL (final sample concentration) inhibited the peak response to urate crystals by $>80 \%$ but did not inhibit the responses to the other stimuli (Table V).

Effects of other plasma proteins on urate crystal-induced $C L$. The quantities of protein bound to urate crystals exposed to 


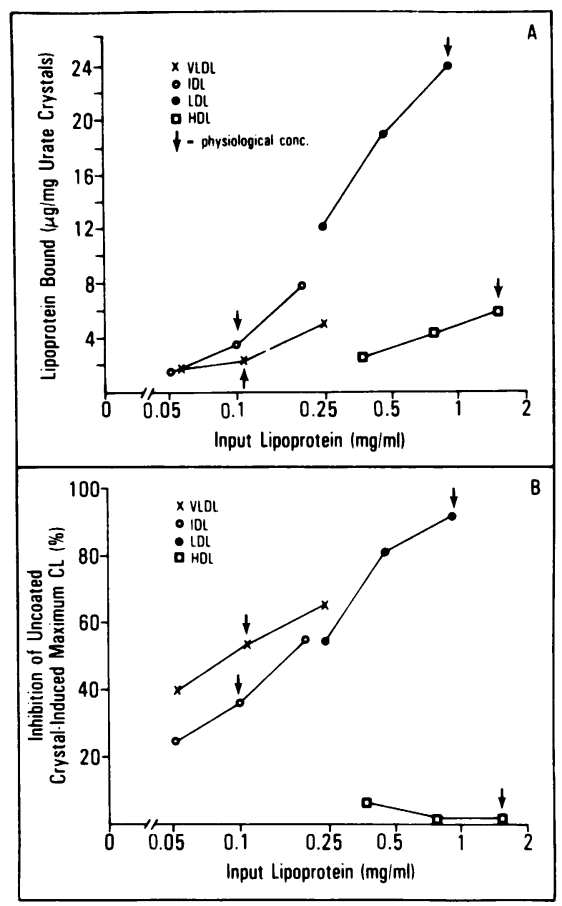
logarithmically. Arrows indicate normal fasting plasma concentrations of the respective lipoproteins in fasting individuals. conc, concentration.

LPDP and reconstituted LPDP were measured by the Lowry assay (51) (see Methods) and were not significantly different in nine different determinations (LPDP $=22 \pm 4.7$ (SEM) $\mu \mathrm{g}$ bound protein $/ \mathrm{mg}$ crystals, reconstituted LPDP $=28.9 \pm 4.5 \mu \mathrm{g} / \mathrm{mg}$ crystals). Values for serum and for citrated and EDTA plasma were similar, lying between $22-26 \mu \mathrm{g} / \mathrm{mg}$ crystals. In addition, other than the lack of lipoprotein polypeptides, the gel patterns of eluates from LPDP-coated crystals were qualitatively similar to those for plasma-coated crystals (Fig. 1). Because bound IgG has been suggested to be important in cellular responses to plasma exposed urate crystals $(7,18,52)$, we investigated possible effects of lipoprotein depletion on IgG binding to crystals. Tracer amounts of ${ }^{125} \mathrm{I}$-labeled IgG were added to urate crystals in the presence of equal concentrations of LPDP and reconstituted LPDP. IgG binding was indistinguishable in the two plasmas (4.7 and $4.6 \%$ of the starting IgG counts were bound, respectively). Thus, lipoprotein depletion did not appear to appreciably alter the overall pattern of crystal-bound proteins other than the apolipoproteins.

We also assessed the effects on CL of the removal of other crystal-binding proteins from plasma or serum. Fibrinogen, fibronectin, IgG, and $\mathrm{Clq}$ were studied because they have been visualized on O'Farrell gels of plasma proteins eluted from urate crystals (Fig. 1) (17). Fibrinogen did not appear to be important in inhibition of urate-induced $\mathrm{CL}$ as serum and plasma had similar effects (Fig. $4 \mathrm{~A}$ ). Plasma, depleted of fibronectin, and serum, depleted of $\mathrm{Clq}$, showed no significant changes in the inhibition of $\mathrm{CL}$ induced by the precoated crystals (Figs. $6 \mathrm{~A}$ and $C$ ). In contrast, an IgG-deficient plasma was slightly more inhibitory than the same plasma reconstituted with deaggregated IgG (Fig. $6 \mathrm{~B}$ ). This was compatible with the previous suggestion of a role for IgG in urate crystal stimulation of neutrophils $(7,18)$.

\section{Discussion}

When the etiologic agent of human gout, the monosodium urate crystal $(1,2)$ is incubated with plasma, a number of proteins are selectively bound (17). In the present work, apo A-I, apo $B$, and apo $E$ were identified by electrophoresis and Western blotting techniques. Binding of intact lipoproteins to the urate crystals was substantiated by demonstration of the association of both apo B and cholesterol with the crystals after incubation with LDL. Strikingly, the bound apo B-containing lipoproteins appeared to account for virtually all of the inhibitory activity of plasma on urate-induced PMN CL and a major portion of the plasma inhibition of superoxide generation and cytolysis. This statement is based on the observation that removal of these lipoproteins by density gradient centrifugation or immunodepletion abrogated or markedly reduced the inhibitory effects of plasma on these reactions. Because the major apo B lipoprotein,

Table V. Stimulus Specificity of LDL Inhibition of $C L$

\begin{tabular}{|c|c|c|c|c|}
\hline \multirow[b]{2}{*}{ Inhibitor } & \multicolumn{4}{|c|}{ Maximum $\mathrm{CL}$ response $(\mathrm{cpm} \pm \mathrm{SEM})$ to: } \\
\hline & $\begin{array}{l}\text { Urate crystals } \\
(2 \mathrm{mg} / \mathrm{ml})\end{array}$ & $\begin{array}{l}\text { Opsonized zymosan } \\
\left(10^{8} \text { particles } / \mathrm{ml}\right)\end{array}$ & $\begin{array}{l}\text { S. aureus } \\
(100 \mu \mathrm{g} / \mathrm{ml})\end{array}$ & $\begin{array}{l}\text { FNLPNTL } \\
(10 \mathrm{nM})\end{array}$ \\
\hline Buffer (PBS) & $2,232,910 \pm 154,515$ & $3,858,677 \pm 722,573$ & $3,558,220 \pm 230,459$ & $776,994 \pm 46,402$ \\
\hline $\operatorname{LDL}(10 \mu \mathrm{g} / \mathrm{ml})$ & $374,740 \pm 2,970$ & $3,820,535 \pm 656,927$ & $3,333,412 \pm 624,046$ & $1,009,914 \pm 23,926$ \\
\hline
\end{tabular}

LDL or buffer was preincubated with the stimuli in a volume of $0.1 \mathrm{ml}$ for $30 \mathrm{~min}$ at $22^{\circ} \mathrm{C}$. Stimuli were then added, without being washed, to triplicate $0.4 \mathrm{ml}$ suspensions of $2.5 \times 10^{5}$ PMNs in HBSS- $0.02 \mathrm{M}$ Hepes- $0.25 \%$ BSA. CL was monitored for 60 min. Indicated stimulus and LDL concentrations are those achieved in the final CL reaction mixture. 

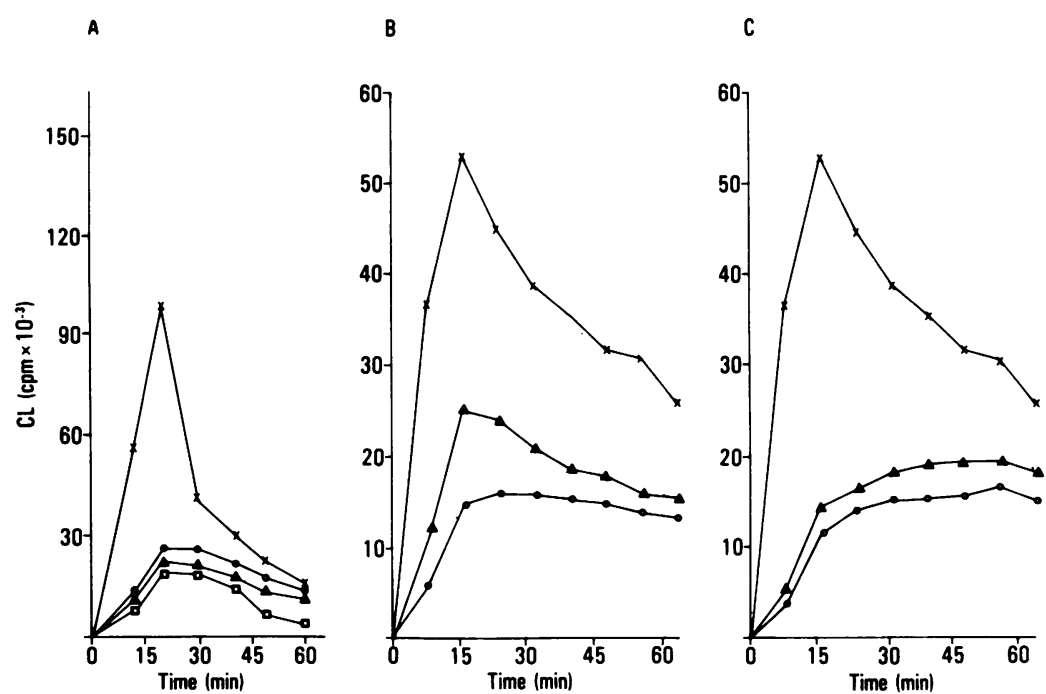

Figure 6. Effects of depletion of other crystal-binding plasma proteins on plasma inhibition of urate crystalinduced CL. $(A)$ Effect of fibronectin: CL responses of PMNs after the addition of urate crystals $(2 \mathrm{mg} / \mathrm{ml})$ coated with buffer $(-\times-)$, plasma depleted of fibronectin by gelatin-Sepharose affinity chromatography (-O -), "sham" fibronectin-depleted (chromatographed on underivatized Sepharose) plasma $(-\square-)$, and fibronectin-depleted plasma reconstituted with fibronectin to $300 \mu \mathrm{g} / \mathrm{ml}(-\Delta-)$. (B) Effect of IgG: $C L$ responses to urate crystals coated with buffer $(-\times-)$, agammaglobulinemic plasma (- - - ), and agammaglobulinemic plasma reconstituted with deaggregated $\mathrm{IgG}$ to $15 \mathrm{mg} / \mathrm{ml}(-\Delta-)$. (C) Effect of Clq: CL responses to urate crystals coated with buffer $(-\times-)$, Clq-depleted serum $(-\mathrm{O}-)$, and Clq-depleted serum reconstituted with $\mathrm{Clq}$ to $70 \mu \mathrm{g} / \mathrm{ml}(-\Delta-)$.

LDL, has an apparent Stoke's radius $\sim 96 \AA$ (53), similar to that calculated from the Stokes-Einstein equation (54) for $\alpha-2$ macroglobulin (100 $\AA$ ), the presence of LDL in synovial fluid, like that of $\alpha-2$ macroglobulin (20), is likely to depend upon the permeability of the synovial membrane. Such predicted wide variations in synovial fluid LDL levels have been observed (19, 55-58) and could greatly affect the inflammatory response to urate crystals or neutrophil peroxidase-dependent catabolism of the crystals (59) in the course of gouty arthritis.

Urate crystal-bound apolipoproteins were visualized on silver-stained two-dimensional O'Farrell gels (Fig. 1, Table I). Identification of each apolipoprotein was suggested by diminution of the spot in question in the O'Farrell gel of the urate pellet of LPDP, and by coelectrophoresis on O'Farrell gels with polypeptides derived from isolated lipoproteins. Western blot analysis provided direct identification of urate crystal-bound apo A-I, apo B, and apo E (Figs. 2 and 3; Table I). A number of smaller LDL-derived polypeptides visualized on silver-stained urate crystal pellet two-dimensional gels (Fig. 1, open arrows), apparent $M_{\mathrm{r}}=90,000-94,000$, were not detected with monoclonal anti-apo B antibodies in the Western blot system (Figs. 2 and 3). These were probably apo B-related as essentially all the protein of LDL exists as apo B (60). A possible explanation for the failure to detect these as apo $B$ species would be the known differential immunochemical reactivity of various apo B species $(27,47)$; alternatively, proteolytic cleavage of apo B during preparation $(47,48)$ and incubation with urate crystals, or the denaturation carried out before electrophoresis may have rendered certain apo B peptides devoid of a suitable epitope for the apo B-specific antibodies.

We investigated the effects of plasma on urate crystal-neutrophil interaction by measurement of luminol-dependent $\mathrm{CL}$, a commonly employed assay system for stimulation of phagocyte oxidative metabolism by particulates (36). Luminol-dependent $\mathrm{CL}$ depends on the generation of superoxide and hydrogen per- oxide and the action of myeloperoxidase $(49,61)$. Previous studies have shown that preincubation of urate crystals with plasma or serum reduces the ability of crystals to induce neutrophil superoxide generation (7) and cytolysis (18). As expected, crystal preincubation with plasma and serum also inhibited CL (Fig. $4 \mathrm{~A}$ ). Depletion of lipoproteins from plasma by density gradient ultracentrifugation completely abrogated the inhibition of urate crystal-induced $\mathrm{CL}$ produced by precoating the crystals with plasma (Fig. $4 \mathrm{~B}$ ). Similar effects were observed on coincubation of plasmas with crystals and cells, indicating that the lipoprotein effect is not limited to coated crystals in plasma-free systems. Lipoproteins also showed similar modulatory effects on neutrophil cytolysis (LDH loss, Table III) and superoxide generation (Table II). Thus, lipoproteins modulate a number of neutrophil responses to urate crystals. The inhibitory activity of lipoproteins on urate-induced $\mathrm{CL}$ appears to reside exclusively with the apo B lipoproteins. First, in reconstitution experiments, apo B lipoproteins (VLDL, IDL, and LDL), but not HDL, contributed inhibitory activity to LPDP (Table IV $A$ ). Second, immunodepletion of apo B lipoproteins by agarose-bound monoclonal antibody also abrogated the inhibitory activity of plasma (Table IV $B$ ). Since most of the circulating apo B under normal circumstances is in LDL (60), LDL probably provides the bulk of this activity. This suggestion was borne out by the observation that physiologic reconstitution of LPDP with LDL produced a more potent inhibitory reagent than reconstitution with other lipoproteins (Table IV $A$ ).

Because many plasma proteins are bound to these crystals, it is possible that the lipoprotein effect on urate-induced $C L$ is mediated through another plasma protein or is a nonspecific protein effect. However, this seems unlikely for several reasons. First, with the exception of the apolipoproteins, the two-dimensional gel electrophoretic patterns of the crystal eluates were similar for LPDP and reconstituted LPDP (Fig. 1). The amount of urate crystal-bound protein also was comparable for LPDP, 
reconstituted LPDP, and unmodified serum and plasma. Second, lipoprotein depletion did not alter the binding of $\operatorname{IgG}$ to the crystals. Third, apo B-containing lipoproteins bound directly to the crystals (Fig. $5 \mathrm{~A}$ ) and inhibited CL (Fig. $5 \mathrm{~B}$ ) in the absence of other added plasma proteins. Fourth, nonspecific inhibition of urate-induced neutrophil cytolysis by plasma proteins is observed in otherwise protein-free crystal-cell suspensions (18). Thus, all CL, superoxide, and cytolysis assays were performed in the presence of $2-2.5 \mathrm{mg} / \mathrm{ml}$ of the "nonspecific protein" BSA, so that additional inhibitory effects, such as those of lipoproteins, could be assessed. Fifth, HDL, bound to crystals in amounts similar to VLDL and IDL, failed to inhibit urateinduced CL (Figs. $5 A$ and $B$ ). Finally, plasmas or sera deficient in, or depleted of, three other major urate-binding plasma proteins still were potent inhibitors of urate-induced CL (Fig. 6).

The ability of apo B-containing lipoproteins to inhibit urateinduced $C L$ was not due to interference with the $C L$ assay or to direct toxic effects on the cells, since response to fluid-phase chemotactic hexapeptide was not reduced by doses of LDL which produced $80 \%$ inhibition of urate-induced CL (Table V). In addition, the possibility that inhibition was due to nonspecific effects on PMN-particle interaction or phagocytosis was less likely since responses to two other particulates were unaffected by LDL.

Elucidation of this novel functional property of apo B-containing lipoproteins will require detailed studies of their effects on other events which follow PMN-crystal interaction, effects with other crystals and cell types, and the lipoprotein structural requirements for this activity. It has been suggested that LDL is a major plasma regulator of HeLa cell adhesion to glass (62), which is a negatively charged surface like monosodium urate crystals. In addition, there is evidence that human serum enhances the stimulation by urate crystals of nonmitogenic synovial fibroblast responses in vitro $(63,64)$. Fibroblasts are known to possess a high affinity receptor for apo B and apo E (65) which might modulate these responses. Thus, the effects observed here may be limited neither to PMNs nor to urate crystals. Furthermore, several transport-unrelated activities of lipoproteins which may modify inflammation-related responses have been recently described (66-71). To these we may add modulation of PMN responses to monosodium urate crystals by apo Bcontaining lipoproteins. Because synovial fluid levels of LDL may vary from trace amounts in normal states to $40-60 \%$ of plasma levels in inflammatory states $(19,55-58)$, LDL may well represent an important factor in modulation of gouty inflammation.

\section{Acknowledgments}

We gratefully acknowledge the discussion and criticism of Dr. C. G. Cochrane. Sandra Diamond-Tissue, Shu-Lan Cheng, D. J. Bonnet, Sherry Young, and Lance Holman provided excellent technical assistance; and Dian Caudebec typed the manuscript.

This work was supported by National Institutes of Health grants AM-27214, HL 28235, AI-18042, and CA-28166. Dr. Ginsberg is a recipient of Research Career Developmental Award AM-00720. Dr. Terkeltaub received fellowship support from the Canadian Arthritis Society and the Medical Research Council of Canada.

\section{References}

1. Faires, J. S., and D. J. McCarty, Jr. 1962. Acute arthritis in man and dog after intrasynovial injection of sodium urate crystals. Lancet II:682-685.

2. Seegmiller, J. E., R. R. Howell, and S. E. Malawista. 1962. The inflammatory reaction to sodium urate: its possible relationship to the genesis of acute gouty arthritis. JAMA (J. Am. Med. Assoc.) 180:469475.

3. S. E. Malawista. 1977. Gouty inflammation. Arthritis Rheum. 20(Suppl.):241-248.

4. Weinberger, A., H. R. Schumacher, and C. A. Agudelo. 1979. Urate crystals in asymptomatic metatarsophalangeal joints. Ann. Intern. Med. 91:56-57.

5. Gordon, T. P., J. V. Bertouch, B. R. Walsh, and P. M. Brooks. 1982. Monosodium urate crystals in asymptomatic knee joints. J. Rheumatol. 9:967-969.

6. Phelps, P., and D. J. McCarty. 1966. Crystal-induced inflammation in canine joints. II. Importance of polymorphonuclear leukocytes. $J$. Exp. Med. 124:115-125.

7. Abramson, S., S. T. Hoffstein, and G. Weissmann. 1982. Superoxide anion generation by human neutrophils exposed to monosodium urate. Effect of protein adsorption and complement activation. Arthritis Rheum. 25:174-180.

8. Simchowitz, L., J. P. Atkinson, and I. Spilberg. 1982. Stimulation of the respiratory burst in human neutrophils by crystal phagocytosis. Arthritis Rheum. 25:181-188.

9. Phelps, P. 1969. Polymorphonuclear leukocyte motility in vitro. III. Possible release of a chemotactic substance after phagocytosis of urate crystals by polymorphonuclear leukocytes. Arthritis Rheum. 12:197-203.

10. Spilberg, I., and B. Mandell. 1983. Crystal-induced chemotactic factor. Adv. Inflammation Res. 5:57-65.

11. Serhan, C. N., V. Lundberg, S. Abramson, B. Samuelsson, and G. Weissmann. 1983. Formation of leukotrienes and hydroxy acids by human leukocytes exposed to monosodium urate. Arthritis Rheum. 26(Suppl.):9.

12. Hoffstein, S., and G. Weissmann. 1975. Mechanisms of lysosomal enzyme release from human leukocytes. IV. Interaction of monosodium urate crystals with dogfish and human leukocytes. Arthritis Rheum. 18:153-165.

13. Ginsberg, M., F. Kozin, D. Chow, J. May, and J. L. Skosey. 1977. Adsorption of polymorphonuclear leukocyte lysosomal enzymes to monosodium urate crystals. Arthritis Rheum. 20:1538-1542.

14. Kozin, F., and D. J. McCarty. 1977. Protein binding to monosodium urate monohydrate, calcium pyrophosphate and silicon dioxide crystals. I. Physical characteristics. J. Lab. Clin. Med. 89:1314-1325.

15. Hasselbacher, P., and H. R. Schumacher. 1978. Immunoglobulin in tophi and on the surface of monosodium urate crystals. Arthritis Rheum. 21:353-361.

16. Hasselbacher, P. 1982. Crystal-protein interactions in crystalinduced arthritis. Adv. Inflammation Res. 4:25-44.

17. Terkeltaub, R., A. Tenner, F. Kozin, and M. H. Ginsberg. 1983. Plasma protein binding by monosodium urate crystals. Analysis by twodimensional gel electrophoresis. Arthritis Rheum. 26:775-783.

18. Kozin, F., M. H. Ginsberg, and J. L. Skosey. 1979. Polymor- 
phonuclear leukocyte responses to monosodium urate crystals: modification by adsorbed serum proteins. J. Rheumatol. 6:519-526.

19. Schmid, K., and M. B. Macnair. 1956. Characterization of the proteins of human synovial fluid in certain disease states. J. Clin. Invest. 35:814-824.

20. Kushner, I., and J. A. Somerville. 1971. Permeability of human synovial membrane to plasma proteins. Relationship to molecular size and inflammation. Arthritis Rheum. 14:560-570.

21. Giclas, P. C., M. H. Ginsberg, and N. R. Cooper. 1979. Immunoglobulin G-independent activation of the classical complement pathway by monosodium urate crystals. J. Clin. Invest. 63:759-764.

22. McCarty, D. J., and J. S. Faires. 1963. A comparison of the duration of local anti-inflammatory effect of several adrenocorticosteroid esters-a bioassay technique. Curr. Ther. Res. Clin. Exp. 5:284-290.

23. Denko, C. W., and M. W. Whitehouse. 1976. Experimental inflammation induced by naturally occurring microcrystalline calcium salts. J. Rheumatol. 3:54-62.

24. Kozin, F., and D. J. McCarty. 1980. Molecular orientation of immunoglobulin $\mathbf{G}$ adsorbed to microcrystalline monosodium urate monohydrate. J. Lab. Clin. Med. 95:49-58.

25. Schreiber, R. D., M. K. Pangburn, A. B. Bjornson, M. A. Brothers, and H. J. Muller-Eberhard. 1982. The role of C3 fragments in endocytosis and extracellular cytotoxic reactions by polymorphonuclear leukocytes. Clin. Immunol. Immunopathol. 23:335-357.

26. Proctor, R. A., E. Prendergast, and D. F. Mosher. 1982. Fibronectin mediates attachment of Staphylococcus aureus to human neutrophils. Blood. 59:681-687.

27. Curtiss, L. K., and T. S. Edgington. 1982. Immunochemical heterogeneity of human plasma apolipoprotein B. I. Apolipoprotein B binding of mouse hybridoma antibodies. J. Biol. Chem. 257:1521315221.

28. Markwell, M. A., S. M. Haas, L. L. Bieber, and N. E. Tolbert. 1978. A modification of the Lowry procedure to simplify protein determination in membrane and lipoprotein samples. Anal. Biochem. 87:206-210.

29. Tsao, B. P., L. K. Curtiss, and T. S. Edgington. 1982. Immunochemical heterogeneity of human plasma apolipoprotein B. II. Expression of apolipoprotein B epitopes on native lipoproteins. J. Biol. Chem. 257:15222-15228.

30. Morrissey, J. H. 1981. Silver stain for proteins in polyacrylamide gels: a modified procedure with enhanced uniform sensitivity. Anal. Biochem. 117:307-310.

31. Voyta, J. C., D. P. Via, J. T. Sparrow, W. A. Bradley, A. M. Gotto, and L. C. Smith. 1982. Monoclonal antibodies to human apolipoprotein E. Fed. Proc. 41:931.

32. Towbin, H., T. Staehelin, and J. Gordon. 1979. Electrophoretic transfer of proteins from polyacrylamide gels to nitrocellulose sheets: procedure and some applications. Proc. Natl. Acad. Sci. USA. 76:43504354.

33. Boyum, A. 1976. Isolation of lymphocytes, granulocytes and macrophages. Scand. J. Immunol. 21(Suppl.):97, 9-19.

34. Chenoweth, D. E., and T. E. Hugli. 1978. Demonstration of specific C5a receptor on intact human polymorphonuclear leukocytes. Proc. Natl. Acad. Sci. USA. 75:3943-3947.

35. Tenner, A. J., and Cooper, N. R. 1982. Stimulation of a human polymorphonuclear leukocyte oxidative response by the $\mathrm{Clq}$ subunit of the first complement component. J. Immunol. 128:2547-2552.

36. Wilson, M. E., M. A. Trush, K. Van Dyke, J. J. Kyle, M. D. Mullet, and W. A. Neal. 1978. Luminol-dependent chemiluminescence analysis of opsonophagocytic dysfunctions. J. Immunol. Methods. 23:315-320.
37. Babior, B. M., R. S. Kipnes, and J. T. Curnutte. 1973. Biological defense mechanisms: the production by leukocytes of superoxide, a potential bactericidal agent. J. Clin. Invest. 52:741-744.

38. Mancini, G., O. Carbonara, and J. F. Heremans. 1965. Immunochemical quantitation of antigens by single radial immunodiffusion. Immunochemistry. 2:235-242.

39. Tenner, A. J., and N. R. Cooper. 1980. Analysis of receptormediated Clq binding to human peripheral blood mononuclear cells. J. Immunol. 125:1658-1664.

40. Hunter, W. M., and F. C. Greenwood. 1962. Preparation of iodine-131 labeled human growth hormone of high specific activity. Nature (Lond.). 194:495-496.

41. Ginsberg, M. H., R. G. Painter, C. Birdwell, and E. Plow. 1979. The detection, immunofluorescent localization, and thrombin-induced release of human platelet-associated fibronectin antigen. J. Supramol. Struct. Cell. Biochem. 11:167-174.

42. Tenner, A. J., P. H. Lesavre, and N. R. Cooper. 1981. Purification and radiolabeling of human Clq. J. Immunol. 127:648-653.

43. Heider, J. G., and R. L. Boyett. 1978. The picomole determination of free and total cholesterol in cells in culture. J. Lipid Res. 19:514518.

44. Gamble, W., M. Vaughan, H. S. Kruth, and J. Avigam. 1978. Procedure for determination of free and total cholesterol in micro- or nanogram amounts suitable for studies with cultured cells. J. Lipid Res. 19:1068-1070.

45. O'Farrell, P. H. 1975. High resolution two-dimensional electrophoresis of proteins. J. Biol. Chem. 250:4007-4021.

46. Kane, J. P., D. A. Hardman, and H. E. Paulus. 1980. Heterogeneity of apolipoprotein B: isolation of a new species from human chylomicrons. Proc. Natl. Acad. Sci. USA. 77:2465-2469.

47. Chapman, M. J., S. Goldstein, and G. L. Mills. 1978. Limited tryptic digestion of human serum low-density lipoprotein: isolation and characterization of the protein-deficient particle and of its apoprotein. Eur. J. Biochem. 87:475-488.

48. Steele, J. C. H., Jr. 1979. The effect of plasmin on human plasma low density lipoprotein. Thromb. Res. 15:573-579.

49. DeChatelet, L. R., G. D. Long, P. S. Shirley, D. A. Bass, M. J. Thomas, F. W. Henderson, and M. S. Cohen. 1982. Mechanism of the luminol-dependent chemiluminescence of human neutrophils. $J$. Immunol. 129:1589-1593.

50. Fredrickson, D. S., and R. I. Levy. 1972. Familial hyperlipoproteinemia. In The Metabolic Basis of Inherited Disease. J. B. Stanburg, editor. McGraw-Hill Book Co., New York. 545-614.

51. Lowry, O. H., N. J. Rosebrough, A. L. Farr, and R. J. Randall. 1951. Protein measurement with the folin phenol reagent. J. Biol. Chem. 193:265-275.

52. Ginsberg, M. H., and F. Kozin. 1978. Mechanisms of cellular interaction with monosodium urate crystals. IgG-dependent and IgGindependent platelet stimulation by urate crystals. Arthritis Rheum. 21:896-903.

53. Shen, B. W., A. M. Scanu, and F. J. Kezdy. 1977. Structure of human serum lipoproteins inferred from compositional analysis. Proc. Natl. Acad. Sci. USA. 74:837-841.

54. Andrews, P. 1969. Estimation of molecular size and molecular weights of biological compounds by gel filtration. In Methods of Biochemical Analysis, Vol. 18. D. Gilick, editor. Interscience, New York. $1-53$.

55. Small, D. M., A. S. Cohen, and K. Schmid. 1964. Lipoproteins of synovial fluid as studied by analytical ultracentrifugation. J. Clin. Invest. 43:2070-2079. 
56. Bole, G. G. 1962. Synovial fluid lipids in normal individuals and patients with rheumatoid arthritis. Arthritis Rheum. 5:589-601.

57. Schmid, K., and M. B. Macnair. 1956. Characterization of the proteins of certain post-mortem human synovial fluids. J. Clin. Invest. 35:708-718.

58. Valente, A. J., and K. W. Walton. 1980. Studies on increased vascular permeability in the pathogenesis of lesions of connective tissue diseases. Ann. Rheum. Dis. 39:490-499.

59. Howell, R. R., and J. E. Seegmiller. 1962. Uricolysis by human leucocytes. Nature (Lond.) 196:482-483.

60. Alaupovic, P. 1980. The concepts, classification systems and nomenclatures of human plasma lipoproteins. In Handbook of Electrophoresis, Vol. 1. L. A. Lewis, and J. J. Opplt, editors. CRC Press, Boca Raton. 27-46.

61. Misra, H. P., and P. M. Squatrito. 1982. The role of superoxide anion in peroxidase-catalyzed chemiluminescence of luminol. Arch. Biochem. Biophys. 215:59-65.

62. Myllyla, G., P. Hayry, K. Penttinen, and E. Saxen. 1966. Serum lipoproteins in primary cell attachment and growth behaviour of cells on glass. Ann. Med. Exp. Fenn. 44:171-176.

63. Hasselbacher, P. 1983. Serum enhances crystal-induced stimulation of synovial fibroblasts. Arthritis Rheum. 26(Suppl.):59.

64. Wigley, F. M., I. T. Fine, and D. S. Newcombe. 1983. The role of the human synovial fibroblast in monosodium urate crystal-induced synovitis. J. Rheumatol. 10:602-611.
65. Brown, M. S., P. T. Kovanen, and J. L. Goldstein. 1981. Regulation of plasma cholesterol by lipoprotein receptors. Science (Wash. DC). 212:628-635.

66. Rosenfeld, S. I., C. H. Packman, and J. P. Leddy. 1983. Inhibition of the lytic action of cell-bound terminal complement components by human high density lipoproteins and apoproteins. J. Clin. Invest. 71:795808.

67. Schwartz, B. S., G. A. Levy, L. K. Curtiss, D. S. Fair, and T. S. Edgington. 1981. Plasma lipoprotein induction and suppression of the generation of cellular procoagulant activity in vitro. J. Clin. Invest. 67:1650-1658.

68. Chisari, F. V., L. K. Curtiss, and F. C. Jensen. 1981. Physiologic concentrations of normal human plasma lipoproteins inhibit the immortalization of peripheral B lymphocytes by the Epstein-Barr virus. $J$. Clin. Invest. 68:329-336.

69. Curtiss, L. K., and T. S. Edgington. 1979. Differential sensitivity of lymphocyte subpopulations to suppression by low density lipoprotein inhibitor, an immunoregulatory human serum low density lipoprotein. J. Clin. Invest. 63:193-201.

70. Benditt, E. P., N. Ericksen, and R. H. Hanson. 1979. Amyloid protein SAA is an apoprotein of mouse plasma high density lipoprotein. Proc. Natl. Acad. Sci. USA. 76:4092-4096.

71. Ulevitch, R. J., A. R. Johnston, and D. B. Weinstein. 1979. New function for high density lipoproteins: their participation in intravascular reactions of bacterial lipopolysaccharides. J. Clin. Invest. 64:1516-1524. 